\title{
Lectins probe molecular films in biofouling: characterization of early films on non-living and living surfaces
}

\author{
Teena Michael, Celia M. Smith
}

Department of Botany, University of Hawai'i, 3190 Maile Way, Honolulu, Hawai'i 96882-2279, USA

\begin{abstract}
Films that form quickly on surfaces immersed in the ocean influence the settlement of microbes and eukaryotic cells via differential distribution of specific receptors that initiate attachment and metamorphosis. This study probed both inert, non-biological surfaces (glass slides) and living surfaces (leaves of seagrass Halophila hawailana) with fluorescently labelled lectins to detect and describe distributions of glycoconjugates deployed on surface films. Lectins from Canavalis ensiformis (Con A) and Limulus polyphemus (limulin) bound particular glycoconjugates in films that formed 1 and $3 \mathrm{~d}$ following immersion of glass slides in Pearl Harbor (Hawai'i, USA) waters. A complex spatial pattern in film development was observed on glass surfaces; approximately circular areas of reduced receptor densities were interspersed in an otherwise homogeneous matrix. The circular area surrounded centrally located aggregates of particles (including microbes) in $1 \mathrm{~d}$ films. The diameter of these zones increased nearly 10 -fold when 1 and $3 \mathrm{~d}$ films were compared. A third lectin from Helix pomatia localized a third set of glycoconjugates in specific filmed areas and with the organic matter associated with bacteria on $3 \mathrm{~d}$ films. Each lectin also bound to surface glycoconjugates on newly emergent leaves of $H$. hawailana with qualitatively different results than those observed for glass. The distributions of receptors for Con A, $H$. pomatia and limulin lectins were less dense on seagrass surfaces than on filmed glass. Also, receptors for limulin and $H$. pomatia lectins were associated with the cell walls and peripheral cytoplasm of seagrass cells, not in surface films on leaves. Con A localized glycoconjugates showed only a faint signal on the cell walls of these young leaves. This technique documents previously undescribed spatial and chemical heterogeneities of early, similarly aged surfaces. This understanding allows the definition and localization of possible microscale cues for biofouling. These early steps are expected to be crucial to the distribution of sessile organisms in marine environments.
\end{abstract}

KEY WORDS: Lectins - Molecular probes - Biofilms - Epifluorescence microscopy - Biofouling

\section{INTRODUCTION}

Lectins, a class of naturally occurring proteins or glycoproteins that bind carbohydrates specifically and noncovalently, have been known for over $100 \mathrm{yr}$. These glycoproteins have now been identified in a variety of biological systems ranging from viruses and bacteria to plants and specific cell types in mammals. Recently. the glycoconjugates, e.g. glycoproteins, glycolipids or polysaccharides deployed on the surfaces of cells, were proposed to provide a consistent molecular mechanism for recognition and even attachment at the cell surface (Sharon \& Lis 1989). In the marine environ- ment, sugars and adhesion-enhancing factors can be common in sea water as biological exudates (Tosteson \& Zaidi 1974, Baier \& Weiss 1975, Tosteson \& Corpe 1975, Tosteson et al. 1976, Jimenez et al. 1979, Decho 1990). This dissolved mix of substances coats newly immersed surfaces as an abiotic conditioning film that matures to a biofilm and may constitute an important step that precedes settlement by juvenile stages of many marine organisms.

Distributions of glycoconjugates on cell surfaces have been demonstrated for species in a variety of algal divisions: the Cyanophyta, Pyrrhophyta, Raphidophyta, Euglenophyta, Chromophyta and Chloro- 
phyta (Surek \& Sengbusch 1981, Vanni et al. 1981, Sengbusch et al. 1982, Sengbusch \& Muller 1983, Imam et al. 1984, Kaska et al. 1988). In unicellular green algae, glycoconjugates are involved in cell-tocell recognition, adhesion, morphogenesis and wall assembly (Imam et al. 1984, Klis et al. 1985, Goodenough et al. 1986, Schlipfenbacher et al. 1986, Samson et al. 1987). Specific glycoconjugates on algal cell surfaces have been detected via light microscopy and the use of a fluorescent chromophore to label the lectin. Emissions from the chromophores have been visualized with epifluorescence microscopy and have localized discrete domains of probe binding on algal surfaces (Surek \& Sengbusch 1981, Vanni et al. 1981, Sengbusch et al. 1982, Sengbusch \& Muller 1983).

At least 2 common planktonic larvae, Janua brasiliensis, a spiroibid polychaete, and Balanus amphitrite, a barnacle, settle differentially in response to specific components in biofilms (Kirchman et al. 1982a, b, Maki et al. 1988). Settlement by $J$. brasiliensis occurs after the formation of bacterial films and in the presence of glycoproteins or polysaccharides. J. brasiliensis settlement is blocked by the addition of Concanavalin $A$ (Con A), a lectin specific to glucose and mannose moieties of larger glycoconjugates (Kirchman et al. 1982a). Settlement and adhesion in 1 alga, Dunaliella tertiolecta, appears to be mediated by lectin(s) in a similar manner to known invertebrate larvae (Maki \& Mitchell 1986).

The use of glass slides as substrates for settlement is common in biofouling studies. Similarly, seagrass leaves provide numerous replicate natural surfaces in meadows where fouling by microbes, algae and invertebrates can be heavy (Novak 1984). These 2 surface types differ in surface tension, hydrophobicity, surface texture and chemistry, and were used here to test how glycoconjugates might be visualized via lectin binding. By comparing glass and seagrass leaf surfaces, we sought ways to characterize microscale features of early film chemistries on non-biological and biological surfaces.

To date, no study has examined the formation of molecular or bacterial films on marine surfaces with fluorescently labelled lectins. This study builds on the observations in the literature that lectin binding sites on surfaces of marine organisms are routinely visualized with epifluorescence microscopy and that at least 1 glycoconjugate directs larval settlement. This technique was developed to facilitate more rapid but precise characterization of surface films generated in laboratory and field settings. This information has great applicability to understanding early, crucial steps in biofouling of man-made and natural surfaces

\section{MATERIALS AND METHODS}

Laboratory films. Films made to test the specificity of Con A lectin binding were generated in the laboratory from reagent-grade glycoconjugate sugars of Con $A$. Drops of $2 \mathrm{M}$ mannose and/or glucose were applied to clean glass slides and oven dried for $12 \mathrm{~h}$ at $56^{\circ} \mathrm{C}$.

Natural films on glass. Marine films were generated on replicate clean glass slides immersed in seawater following standard methods at the ONR/University of Hawai'i fouling test site, Pearl Harbor, O'ahu, Hawai'i, USA (Rittschoff et al. 1992). Slides were suspended in seawater from racks by monofilament line within $0.25 \mathrm{~m}$ of the surface. Filmed slides were harvested at 1 and 3 d intervals during October 1991 and transported to the lab in Coplin jars filled with $0.4 \mu \mathrm{m}$ fil tered seawater or $2 \%$ formalin in filtered seawater.

Natural films on a living surface. The Hawaiian seagrass Halophila hawailana Doty and Stone was collected from discrete patches $2 \mathrm{~m}$ deep and $50 \mathrm{~m}$ offshore from Malaekahana, O'ahu. Newly emergent leaves (between 1 and 3 d old) were selected. These leaves do not have the epiphytic colonization that was evident on older leaves. The seagrass leaves were transported to the lab in $0.4 \mu \mathrm{m}$ filtered seawater or $2 \%$ formalin in filtered seawater. Samples were probed for lectin binding and examined on the day they were harvested.

Application of lectins. Commercially prepared lectins, each conjugated with a specific fluorescent chromophore, were obtained from Sigma Chemical Co. Specific couplings of lectins and chromophores were selected based on expectations of chemical elements in natural films and non-overlapping chromophore emission wavelengths. Lectins of differing sugar specificities were used to detect different sugar residues on the surfaces. The lectins chosen were derived from Helix pomatia (with Texas Red as chromophore, abbreviated as 'Helix lectin + Texas Red' or 'Helix lectin + FITC'), Limulus polyphemus ('limulin + FITC'), Canavalis ensiformis ('Con A lectin + FITC' or 'Con A lectin + TRITC') (excitation and emission wavelengths per chromophore are given in Table 1). The sugar specificities per lectin are given in Table 2 .

To test for the specificity of lectin-glycoconjugate interaction for Con A lectin binding, artificial films were incubated with a hapten to Con $\mathrm{A}(0.1 \mathrm{M}$ solution of $\alpha$-methyl-D-mannoside) along with Con A lectin + FITC.

Glass slides with 1 and 3 d films were incubated for $30 \mathrm{~min}$ in solutions of $250 \mu \mathrm{m} \mathrm{ml}^{-1}$ lectin + fluorescent chromophore, in EPES buffer, $50 \mathrm{mM}$, at pH 7.8. Multiple lectin staining was carried out using the probe with the highest amount of fluorescent molecule to protein first, washed then stained with subsequent lectins (e.g. 
Table 1 Excitation and emission wavelengths for fluorescent chromophores available with many lectins

\begin{tabular}{|lll|}
\hline Chromophore & Excitation range (nm) & Emission max (nm) \\
\hline FITC (fluorescein isothiocyanate) & UV to 495 (blue) & 535 (green) \\
TRITC (tetramethylrhodamine isothiocyanate) & UV to 557 (green) & 576 (yellow/orange) \\
Texas Red (sulforhodamine 101 acid chloride) & UV to 596 (yellow/orange) & 615 (orange/red) \\
DAPI (4,6-diamidino-2-phenylindole) & 360 (UV) & 490 (blue) \\
\hline
\end{tabular}

Table 2. Sugar specificity and molecular characterizations of common lectins

\begin{tabular}{|c|c|c|c|c|}
\hline Lectin source & Common name & Mol. wt (Da) & Sugar specificity & Reference \\
\hline Canavalis ensiformis & Concanavalin A & 102000 & $\alpha$-D-mannosyl, $\alpha$-D-glucosyl residues & Reeke et al. (1974) \\
\hline Helix pomatia & & 79000 & $\mathrm{~N}$-acetyl- $\alpha$-D-galactosaminyl residues & Hammarstrom et al. (1972) \\
\hline Limulus polyphemus & Limulin & 400000 & $\begin{array}{l}\text { N-acetylneuraminic acid, } \\
\text { glucuronic acid, phosphorycholine } \\
\text { analogs }\end{array}$ & $\begin{array}{l}\text { Fernandez-Moran et al. (1968), } \\
\text { Marchelonis \& Edelman (1968), } \\
\text { Gibride \& Pistole (1979) }\end{array}$ \\
\hline
\end{tabular}

limulin with $5 \mathrm{~mol}$ FITC $\mathrm{mol}^{-1}$ protein, Con A with $0.5 \mathrm{~mol}$ TRITC $\mathrm{mol}^{-1}$ protein). To distinguish prokaryotic cells from organic matter, DAPI $\left(10 \mu \mathrm{g} \mathrm{ml}^{-1}\right)$ was added to the final lectin solution for the last 5 min of the incubation. Finally, the samples were fixed for $30 \mathrm{~s}$ in $2 \%$ buffered formalin in filtered seawater. Unbound lectin and DAPI were removed by rinsing samples with 3 changes of distilled water.

Microscopy. Films were examined with an Olympus BHS microscope equipped with a $\mathrm{BH} 2-\mathrm{RFC}$ reflected fluorescence attachment. Emission from the $100 \mathrm{~W}$ high-pressure mercury burner ranged from ca 280 to $600 \mathrm{~nm}$. Excitation beams of ultraviolet (ca 300 to $400 \mathrm{~nm}$ with $365 \mathrm{~nm}$ max.), blue (ca 360 to $500 \mathrm{~nm}$ with ca $475 \mathrm{~nm}$ max.) or green wavelengths (ca 450 to $550 \mathrm{~nm}$ with ca $545 \mathrm{~nm}$ max.) were selected based on the chromophore in use (see Table 1). Observations for quality and spatial distribution of emission signals were made via non-fluorescent DPlan APO UVPI $20 x$ and $100 \times$ lens. Photomicrographs were recorded on Kodak Gold film (ASA 1600) with an Olympus model PM-10ADS automatic photomicrographic system corrected with color reciprocity. Low-level autofluorescence by unprobed control samples was visualized for background emission and recorded when possible.

\section{RESULTS}

\section{Single lectin studies in artificial films}

Artificially generated films of mannose or glucose demonstrated the expected positive binding by Con $A$ (Table 1, Fig. 1) while an unstained artificial film under blue excitation showed no sign of positive lectin local- ization. The use of the Con A + FITC combination resulted in bright emission revealing film crenulations, a probable artifact of the drying routine (Fig. 1). Emission by the labelled Con A was undetectable following competitive incubation of an artificial film with a glycoconjugate competitor, $\alpha$-methyl mannoside.

\section{Lectin studies of 1 and 3 d natural films on glass}

Photographic exposures of unprobed 1 and $3 \mathrm{~d}$ old films on glass slides were possible only occasionally because of autofluorescence from microbes or organic matter (Fig. 2). Visualization of early biofilm organisms was enhanced with DAPI stain (Fig. 3). Autofluorescence, DAPI, lectin responses and film details were consistent in replicates regardless if samples were preserved in formalin or probed as fresh films (without fixation or drying). As with the artificial film, emission by the Con $\mathrm{A}+$ chromophore was undetectable following co-incubation of 1 and $3 \mathrm{~d}$ natural films with the sugar competitor, $\alpha$-methyl-D-mannoside.

In contrast, lectin probes of $1 \mathrm{~d}$ natural marine films on glass slides revealed circular patterns in glycoconjugate distributions, specific to Con A (Fig. 4) and limulin (Fig. 5) binding sites. In each case, glycoconjugates appear to differ in concentration relative to clusters of central, DAPI-stained bacteria or particles (Figs. 4 \& 5). The film matrix was rich in Con A receptors (Table 2: glycoconjugates with glucose and/or mannose moieties) where the signals gave bright (high concentration) as opposed to dark (low concentration) receptor regions in the film (Fig. 4). The highest concentration of binding sites for limulin was in discrete areas near microcolonies of bacteria (arrow in Fig. 5). 


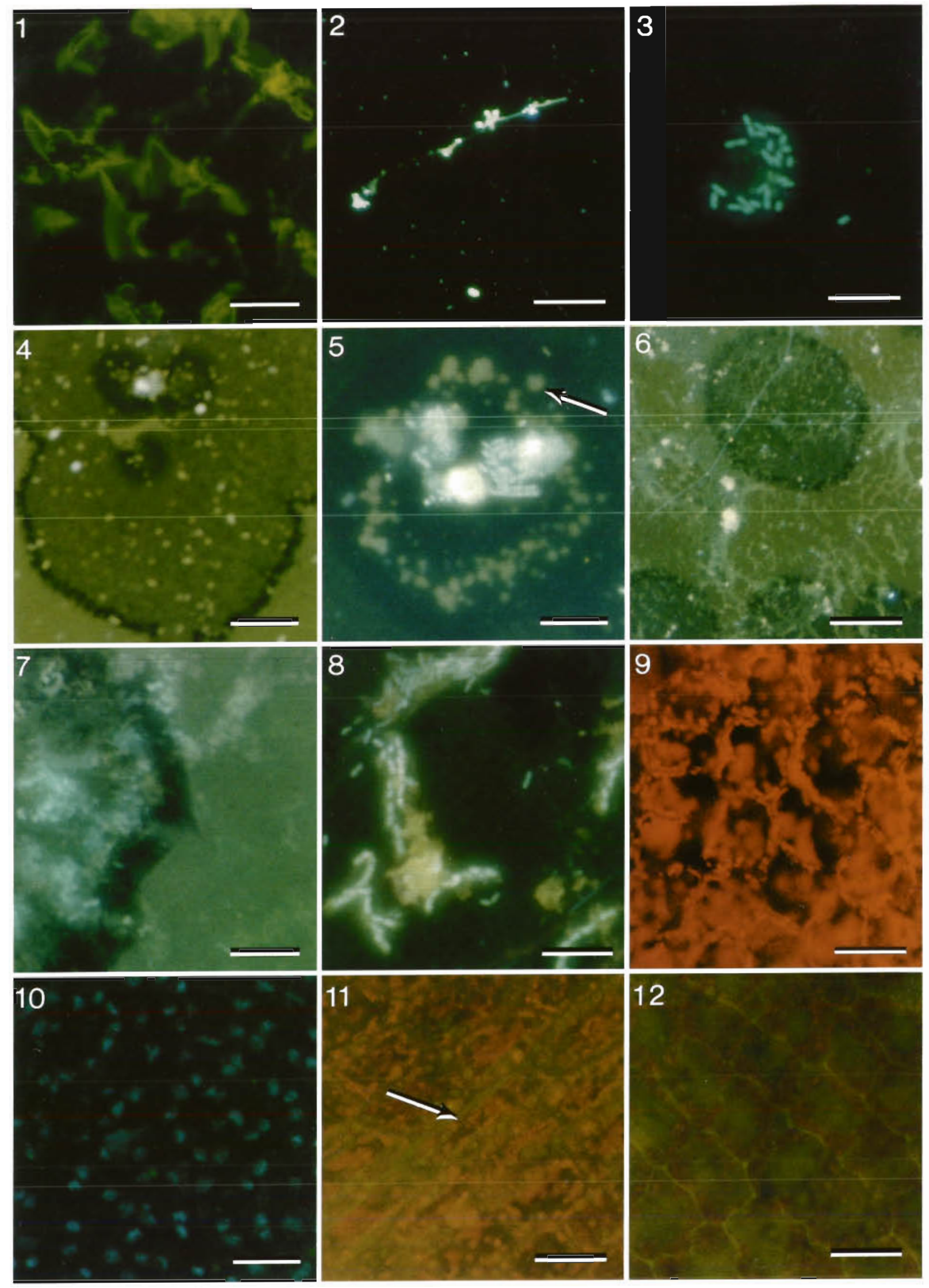


Multiple lectin probes with Con $\mathrm{A}$ and limulin on the $1 \mathrm{~d}$ films revealed no greater film complexity.

Three day old natural films on glass were similar to $1 \mathrm{~d}$ films in that the spatial heterogeneity of the film was still evident (Figs. 6 \& 7). The circular zone diameters increased from 8 to $18 \mu \mathrm{m}$ to 35 to $85 \mu \mathrm{m}$. An apparent shift in chemistry of the $3 \mathrm{~d}$ films was shown by the co-occurring limulin and Con A receptor molecules in the matrix of the film (Figs. 6 \& 7). The Con A + TRITC signal was clearest within the dark circular areas (confirmed by green excitation; not shown). Aggregates of bacteria that were central to concentric bands in the $1 \mathrm{~d}$ films were not visible in $3 \mathrm{~d}$ films although scattered bacteria and microcolonies were found (Figs. 6 to 8). Extracellular polymeric secretions from bacteria bound Helix pomatia lectin + Texas Red (Fig. 8, Table 2).

\section{Lectin studies of a newly emergent living substrate}

Initially, whole-mounted seagrass leaves were assessed for background autofluorescence. Chloroplasts were the major source of autofluorescence following excitation by blue wavelengths (Fig 9). Both limulin and Helix pomatia lectins bound components in newly emergent seagrass cell walls. Distinct nuclei were resolved using DAPI localization (Fig. 10). The use of limulin + FITC revealed a positive response to apparently diffuse receptor densities in periclinal cell walls and a brighter signal from anticlinal walls in the elongate cells over veins (arrow in Fig. 11).

Anticlinal cell walls and cell matrices demonstrated a positive response to Helix pomatia lectin + FITC
(Fig. 12). Upper cell matrices were sources of the signal as resolved via through-focal examination. This area of epidermal cells is generally rich in chloroplasts, mitochondria and secretory organelles; the probes may have localized glycoprotein-rich synthesis compounds and/or metabolic products. Epifluorescent emission from the young seagrass surface was attributed to specific binding with the cell walls in contrast to the natural films on glass (compare Figs. 11 \& 12 with Fig. 6). No microbes or surface films were detected on any young leaves in this study.

\section{DISCUSSION}

Epifluorescence microscopy coupled with lectin specificity offers a new way to probe rapidly and precisely the spatial relationships of complex molecular distributions on marine surfaces when films are present. Glycoconjugates were clearly present in these early films on inert surfaces in sufficient concentrations to allow their visualization and localization with lectin probes. Clear but differential binding of selected lectins also revealed a marked degree of spatial differentiation in early films that formed repeatedly and consistently on glass surfaces. In marked contrast, no films were detected on surfaces of young seagrass leaves. Finally, with the maturation of a conditioning film on glass surfaces, the identity, spatial pattern and numbers of glycoconjugates changed and increased respectively. This evidence for a chemical shift in 1 to $3 \mathrm{~d}$ films came from early dominance of Con A receptors to co-dominance of Con $\mathrm{A}$ and limulin receptors in the film matrix. The mechanisms that formed circular pat-

Fig. 1. A positive signal from Con A + FITC bound to a glucose film. Blue wavelength excitation. Scale bar $=25 \mu \mathrm{m}$

Fig. 2. Autofluorescence from unstained $3 \mathrm{~d}$ films on glass. UV wavelength excitation. Scale bar $=25 \mu \mathrm{m}$

Fig. 3. Bacteria in a $3 \mathrm{~d}$ film on glass localized by DAPI staining. UV wavelength excitation. Scale bar $=2 \mu \mathrm{m}$

Fig. 4. Distinct spatial pattern of glycoconjugate distribution in the matrix of a $1 \mathrm{~d}$ film on glass revealed by Con A + FITC $i$ DAPI localized bacteria. Scale bar $=2 \mu \mathrm{m}$

Fig. 5. Lectin probe, limulin + FITC. A circular pattern of distribution for a limulin + FlTC specific glycoconjugate (arrow) and DAPI localized microcolony of bacteria of a $1 \mathrm{~d}$ film on glass. UV wavelength excitation. Scale bar $=2 \mu \mathrm{m}$

Fig. 6. Complex spatial pattern on glass in a $3 \mathrm{~d}$ film on glass was revealed by limulin + FlTC, Con A lectin + TRITC, and DAPI staining. Microcolonies overlie glycoconjugate matrix. UV wavelength excitation. Scale bar $=25 \mu \mathrm{m}$

Fig. 7. Magnified area of Fig. 6 reveals heterogeneity of receptor densities. UV wavelength excitation. Scale bar $=2 \mu \mathrm{m}$

Fig. 8. Glycoconjugates specific to Helix pomatia lectin (+ Texas Red) are localized in the extracellular polymeric secretions of DAPI-stained bacteria in $3 \mathrm{~d}$ films on glass. UV wavelength excitation. Scale bar $=2 \mu \mathrm{m}$

Fig. 9. Halophila hawaiiana. Autofluorescence by cells of newly emergent seagrass leaves. Blue wavelength excitation. Scale bar $=25 \mu \mathrm{m}$

Fig. 10. Halophila hawailana. DAPI-stained nuclei of seagrass cells. UV wavelength excitation. Scale bar $=25 \mu \mathrm{m}$

Fig. 11. Halophila hawaiiana. Epidermal cells as revealed via limulin (+ FITC). Lectin receptors were concentrated in anticlinal walls over veins (arrow). Blue wavelength excitation. Scale bar $=25 \mu \mathrm{m}$

Fig. 12. Halophila hawaiiana. Epidermal cell walls as revealed via Helix pomatia lectin + FITC. Lectin receptors were concentrated in the upper cell matrix and anticlinal walls. Blue wavelength excitation. Scale bar $=25 \mu \mathrm{m}$ 
terns in the films on glass are not known. Two explanations are possible. The circular patterns could result from periodic precipitation of chemicals in the film as a gel. In this case, diffusion from point sources (inorganic, organic or microbes) could occur as in the formation of 'Liesegang' bands (Williams 1938a, b, $1939 a, b$, Crowle et al. 1963). The edge pattern is then set by the limit of diffusion from the source. Alternatively, the circular patterns could result from the metabolism of central organisms as their metabolic requirements deplete the surrounding region of nutrients (Wimpenny 1981). These and other mechanisms that might create the film patterns can now be evaluated at a scale sufficient to resolve heterogeneity of extremely early stages of filming.

Early films have been viewed as both a precursor to and a physical presence between settled organisms and the immersed surface (e.g. Baier 1973, Schrader et al. 1988). A variety of glycoprotein and lectin sites may be present on these surfaces and are likely to enhance the adhesion of cells and other particulate matter by acting as recognition sites or settlement cues (e.g. Kirchman et al. 1982a, Maki \& Mitchell 1986). Biofilms facilitate adhesion by some organisms or metamorphosis of at least 1 invertebrate (Kirchman et al. 1982b). Bacterial polysaccharides or glycoproteins in a biofilm form complementary bonds with lectins as settlement cues in Janua brasiliensis (Kirchman et al. 1982a). Bacterial settlement on the alga Chlorella vulgaris is enhanced by lectin-like receptors on bacterial surfaces (Imam et al. 1984). Specific epiphytic associations of algal propagules with macrophytes may involve surface recognition mechanisms (Clarke \& Knox 1978, Ducker \& Knox 1984). As a result of this epifluorescence study, a filmed surface can now be viewed as a heterogeneous series of microhabitats. Patterns in settlement that might result from these microhabitats could generate patterns in ultimate community development and thus greatly influence community structure and dynamics.

If early films on glass surfaces were chemically diverse and spatially dynamic within $24 \mathrm{~h}$ of immersion, then early films on comparably aged leaves of Halophila hawaiiana were markedly distinct. A biological system can have a different time course, chemistry and spatial patterning for film formation over even a short, $3 \mathrm{~d}$ period. Newly emergent leaves were not attractive to colonists at least in part because common settlement sites were not present on the leaf surface.

Additionally, it may not be surprising to detect glycoconjugates in leaves of seagrasses; many inter-and intracellular functions for plant activities have been attributed to glycoproteins (Oseroff et al. 1973, Pusztai 1991). Glycoproteins in plant cell walls are involved in growth, organization of cell wall deposition, osmotic relations and permeability that can lead to concentration of nutrients and toxins at the cell wall/ plasmalemma boundary (Cook \& Stoddart 1973). Plant lectins also interact with microorganisms in the formation of symbiotic relationships (Etzler 1986, Pusztai 1.991), as a means of defence against bacteria and viruses (Etzler 1986), and as a source of bacterial infection. As carbohydrate receptor molecules they aid in transport of carbohydrates and membrane stabilization (Etzler 1986).

Cellular expression of certain glycoconjugates depends on the developmental and physiological states as illustrated in algal systems (Surek \& Sengbusch 1981, Sengbusch et al. 1982). Seagrass walls are clearly rich in carbohydrates that provide general cell wall functions including structural integrity and, combined with the plasmalemma, regulation and exchange of solutes between the cytoplasm and external environment (Waldron et al. 1989, Kuo et al. 1990). Surface structure components that include Con A receptors such as D-glucose and D-mannose on the surface of a unicellular alga have been implicated in a surface recognition process (Reisser et al. 1982). Cell-tocell and cell-to-substratum adhesion are processes whereby cells recognize and adhere to each other in crucial and complicated events. We have localized molecules with known receptor components for both the glass and seagrass surfaces. Future studies of biological surfaces could (1) characterize specific receptor molecules, and (2) assess the relationships of glycoconjugates with cells, as well as characterize receptors on settling stages.

Understanding the early chemistry of surfaces on which communities develop may provide important insights into the earliest steps that establish communities. We have shown that early films that form on inert glass surfaces in the marine environment are chemically complex and spatially heterogeneous. Additionally, no acellular film was found on young seagrass leaves. These surfaces lacked microbes. From this effort it is clear that epifluorescence microscopy allows rapid, sensitive probing of surface features. This technique can be used to determine the chemical nature of the film relevant to settlement and the spatial patterns of potential binding sites for microbes as well as settling stages of larvae and algae.

Acknowledgements. This research was supported by the Department of Botany, University of Hawai'i, the U.S. Office of Naval Research Grants No. N00014-90-J-1932, N00014-931.0598 and Hawai'i Natural Energy Institute, University of Hawai'i, Honolulu, Hawai'i. This work was enhanced by our contacts with researchers from diverse fields. We appreciate the helpful advice and encouragement of the late Dr Sanford Siegel (biochemistry and geochemistry) and the support and 
interest of Dr Michael Hadfield (marine zoology), Dr Randall Alberte (physiological ecology of marine macrophytes and biofouling) and Dr lsabella Abbott (algal systematics).

\section{LITERATURE CITED}

Baier, R. (1973). Influence of initial surface conditioning of materials on bio-adhesion. In: Acker, R. F., Brown, D. F., DePalma, J. R., Iverson, W. D. (eds.) Proc. 3rd Int. Cong. on Marine Corrosion and Fouling. Northwestern University Press, Evanston, IL

Baier, R. E., Weiss, L. (1975). Demonstration of the involvement of adsorbed proteins in cell adhesion and cell growth. Adv. Chem. Ser. 145: 300-307

Clarke, A. E., Knox, R. B. (1978). Cell recognitions in flowering plants. Q. Rev. Biol 53: 3-28

Cook, G. M. W., Stoddart, R. W. (1973). Surface carbohydrates of the eukaryotic cell. Academic Press, London

Crowle, A. J., Lueker, D. C., Gaskill, H. S. Jr (1963). Periodic (Liesegang) precipitation of chemicals. Nature 199: $623-624$

Decho, A. W. (1990). Microbial exopolymer secretions in ocean environments: their role(s) in food webs and marine processes. A. Rev. Oceanogr. mar. Biol. 28: 73-153

Ducker, S. C., Knox, R. B. (1984). Epiphytism at the cellular level with special reference to algal epiphytes. In: Linskens, H. F., Heslop-Harrison, J. (eds.) Cellular interactions. Springer-Verlag, Berlin, p. 113-133

Etzler, M. E. (1986). Distribution and function of plant lectins. In: Liener, I. E., Sharon, N., Goldstein, I. J. (eds.) The lectins. Academic Press, Orlando, p. 371-425

Fernandez-Moran, H., Marchalonis, J. J., Edelman, G. M. (1968). Electron microscopy of a hemagglutinin from Limulus polyphemus. J. molec. Biol. 32: 467-469

Gilbride, K. J., Pistole, T. G. (1979). Isolation and characterization of a bacterial agglutinin in the serum of Limulus polyphemus. Prog. clin. Biol. Res. 29: 525-535

Goodenough, U. W., Gebhart, B., Mechan, R. P., Heuser, J. E (1986). Crystal of Chlamydomonas reinhardii cell wall polymerization, depolymerization and purification of glycoprotein monomers. J. Cell Biol. 103: 405-418

Hammarstrom, S., Weston, A., Bjork, I. (1972). Subunit structure of Helix pomatia A hemagglutinin. Scand. J Immunol. 1: 295-309

Imam, S. H., Bard, R. F., Tosteson, T R. (1984). Specificity in marine microbial surface interactions. Appl. environ Microbiol 48: 833-839

Jimenez, B. R., Tosteson, T. R., Zaidi, B. R., Tasi, T. S., Atwood, D. K. (1979). Adhesion enhancing organics in the Eastern Caribbean Sea. In: Stewart, H. B. (ed.) CICAR II Symposium of Progress in Marine Research in the Caribbean and Adjacent Regions. FAO Fisheries Report 2000. FAO, Rome

Kaska, D. D., Polne-Fuller, M., Gibor, A. (1988). Developmental studies in Porphyra (Bangiophyceae). II. Characterization of the major lectin binding glycoproteins in differentiated regions of the Porphyra perforata thallus. J. Phycol. 24: $102-107$

Kirchman, D., Graham, S., Reish, D., Mitchell, R. (1982a). Lectins may mediate in the settlement and metamorphosis of Janua (Dexiospira) brasiliensis Grube (Polychaeta: Spirorbidae). Mar. Biol. Lett, 3: 131-142

Kirchman, D., Graham, S., Reish, D., Mitchell, R. (1982b). Bacteria induce settlement and metamorphosis of Janua (Dexiospira) brasiliensis Grube (Polychaeta: Spirorbidae). J. exp. mar. Biol. Ecol. 56: 153-163

Klis, F. M., Samson, M. R., Touw, E., Musgrave, A., van den
Ende, H. (1985). Sexual agglutination in the unicellular green algal Chlamydomonas eugametos. Identification and properties of the mating type plus agglutination factor Plant Physiol. 159: 740-746

Kuo, J., Ridge, R. W., Lewis, W. V. (1990). The leaf internal morphology and ultrastructure of Zostera muelleri Irmisch ex. Aschers. (Zosteraceae): a comparative study of the intertidal and subtidal forms. Aquat. Bot. 36: 217-236

Maki, J. S., Mitchell, R. (1986). The function of lectins in interactions among marme bacteria, invertebrates, and algae. In: Mirelman, D. (ed.) Microbial lectins and agglutins. John Wiley and Sons, New York, p. 409-425

Maki, J. S., Rittschof, D., Costlow, J. D., Mitchell, R. (1988). Inhibition of attachment of larval barnacles, Balanus amphitrite, by bacterial surface films. Mar Biol. 97 : 199-206

Marchelonis, J. J., Edelman, G. M. (1968). Isolation and characterization of a hemagglutinin from Limulus polyphemus. J. molec. Biol. 32: 453-465

Novak, R. (1984). A study in ultra-ecology: microorganisms on the seagrass Posidonia oceanica. P.S.Z.N. I: Mar. Ecol. 5: $143-190$

Oseroff, A. R., Robbins, P. W., Burger, M. M. (1973). The cell surface membrane: biochemical aspects and biophysical probes. A. Rev. Biochem. 42: 647-682

Pusztai, A. (1991). Plant lectins. Cambridge University Press, Cambridge

Reeke, G. N., Becker, J. W., Cunningham, B. A., Gunter, G. R., Wang, J. L., Edelman, G. M. (1974). Relationships between the structure and activities of Concanavalin $A$. Annls N.Y. Acad. Sci. 234: 369-382

Reisser, W., Radunz, A., Wiessner, W. (1982). Participation of algal surface structures in the cell recognition process during infection of aposymbiotic Paramecium bursaria with symbiotic chlorellae. Cytobios 33: 39-50

Rittschoff, D., Claire, A. S., Gerhardt, D. J., Bonaventura, J., Smith, C. M., Hadfield, M. G. (1992). Short term field assessment of antifouling and foul-release coatings. Biofouling 6: 181-192

Samson, M. R., Klis, F. M., Homan, H. L., van Egmond, P., Musgrave, A., van den Ende, H. (1987). Composition and properties of the sexual agglutinins of the flagellated green alga Chlamydomonas eugametos. Planta 170 : $314-22$

Schlipfenbacher, R., Wenzel, S., Lottspeich, F., Sumper, M. (1986). An extremely hydroxyproline-rich glycoprotein is expressed in inverting Volvox embryos. FEBS Lett. 209: $57-62$

Schrader, M. E., Cardamone, J A., Loeb, G. I., Arora, O. P. (1988). Electron spectroscopy and conditioning films on metal. In: Thompson, M. F., Sarojini, F. R., Nagabhushanam, R. (eds.) Marine biodeterioration: advanced techniques applicable to the Indian Ocean. A. A. Balkema, Rotterdam, p. 261-297

Sengbusch, P. v., Mix, M., Wachholz, I., Manshard, E. (1982). FITC-labelled lectins and Calcofluor White ST as probes for the investigation of the molecular architecture of cell surfaces. Studies on conjugatophycean species. Protoplasma 111: $38-52$

Sengbusch, P. v., Muller, U. (1983). Distribution of glycoconjugates at algal cell surfaces as monitored by FITCconjugated lectins. Studies on selected species from Cyanophyta, Pyrrhophyta, Raphidophyta, Euglenophyta, Chromophyta and Chlorophyta. Protoplasma 114: 103-113

Sharon, N., Lis, H. (1989). Lectins as cell recognition molecules. Science 246: $227-234$ 
Surek, B., Sengbusch, P. v. (1981). The localization of galactosyl residues and lectin receptors in the mucilage and cell walls of Cosmocladium saxonicum (Desmidaceae) by means of fluorescent probes. Protoplasma 108: 149-161

Tosteson, T. R., Atwood, D. K., Tsai, R. S. C. (1976). Surface active organics in the Caribbean Sea. In: Oceans 76 Symposium. Marine Technology Society, New York, p. 1C31$1 \mathrm{C} 37$

Tosteson, T R., Corpe, W A. (1975). Enhancement of adhesion of marine Chlorella vulgaris to glass surface. Can. J. Microbiol. 21. 1025-1031

Tosteson, T R., Zaidi, B. R. (1974). Surface active macromolecules in the marine environment: a sugar specific lectinlike activity. In: Weber, H. W., Ruggieri, G. D. (eds.) Food and drugs from the sea symposium. Marine Technology Society, Washington, DC, p. 457-466

Vanni, G. L., Bonora, A., Dall'olio, G. (1981). Distribution of the receptors for Concanavalin $A$ on the surface of Euglena gracilis as revealed by fluorescence microscopy.

This article was submitted to the editor
Plant Sci. Lett. 22 23-28

Waldron, K. W. Baydoun, E. A., Baydoun, H., Brett, C. T (1989). Comparison of cell wall composition of tissues from the seagrasses Halophila and Halodule. Aquat. Bot. 35: $209-218$

Williams, J. W. (1938a). Bacterial growth 'spectrum' analysis I. Methods and application. Am. J. Med. Tech. 4: 58-61

Williams, J. W. (1938b). Bacterial growth 'spectrums'. II. Their significance in pathology and bacteriology. Am. J. Pathol. 14: $642-645$

Williams, J. W. S. (1939a). The nature of gel mediums as determined by various gas tensions and its importance in growth of microorganisms and cellular metabolism. Growth 3: 181-196

Williams, J. W. S. (1939b). Growth of microorganisms in shake cultures under increased oxygen and carbon dioxide tensions. Growth 3: 21-33

Wimpenny, J. W. T (1981). Spatial order in microbial ecosystems. Biol. Rev. 56: 295-324

Manuscript first received: June 20,1994

Revised version accepted: December 5, 1994 